University of Montana

ScholarWorks at University of Montana

4-1999

\title{
Toward an Evolutionary Understanding of Song Diversity in Oscines
}

Erick Greene

University of Montana - Missoula, erick.Greene@mso.umt.edu

Follow this and additional works at: https://scholarworks.umt.edu/biosci_pubs

Part of the Biology Commons

Let us know how access to this document benefits you.

\section{Recommended Citation}

Greene, Erick, "Toward an Evolutionary Understanding of Song Diversity in Oscines" (1999). Biological Sciences Faculty Publications. 296.

https://scholarworks.umt.edu/biosci_pubs/296

This Editorial is brought to you for free and open access by the Biological Sciences at ScholarWorks at University of Montana. It has been accepted for inclusion in Biological Sciences Faculty Publications by an authorized administrator of ScholarWorks at University of Montana. For more information, please contact scholarworks@mso.umt.edu. 


\title{
The Auk
}

A Quarterly

Journal of Ornithology

Vol. 116 No. 2 April 1999

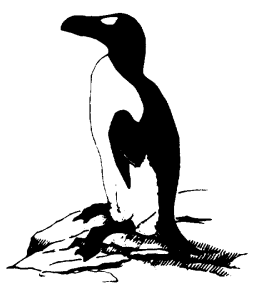

The Auk 116(2):299-301, 1999

OVERVIEWS

\section{TOWARD AN EVOLUTIONARY UNDERSTANDING OF SONG DIVERSITY IN OSCINES}

\author{
ERICK GREENE ${ }^{1}$ \\ Division of Biological Sciences, University of Montana, Missoula, Montana 59812, USA
}

THE SONGS OF BIRDS are among the most complex and beautiful natural sounds, and they have captivated scientists, musicians, poets, and artists for thousands of years. Indeed, the vocal behavior of birds arguably has been studied more intensively than any other aspect of avian biology. Oscine songbirds develop their songs through complex interactions between innate (i.e. genetic, or hard-wired) species-specific developmental programs and social interactions (i.e. learning) during early life. The importance of learning in song development has long been recognized: teaching young birds to imitate melodies was a lucrative profession in Europe during the 17th and 18th centuries. Chicks were kept together in "classes" and exposed to tunes played on recorders. Once the young birds had copied these songs, they commanded high prices at home and abroad. The "Bird Fancyer's Delight" (Anonymous 1717), most likely compiled by the British ornithologist John Hamersley, contains many tunes "properly composed, within ye compass and faculty of each bird, for ye Wood-lark, Blackbird, Throustill, House-sparrow, Canary-bird, Black-thorn-Linnet, Garden-Bull-finch, and Starling."

The interactions between learning and innate developmental events produce a bewildering diversity of vocal behavior among songbirds. Repertoire size (the number of songs sung by

\footnotetext{
${ }^{1}$ E-mail: egreene@selway.umt.edu
}

an individual male), for example, varies over three orders of magnitude. The number of song types an individual male sings varies from one (e.g. White-crowned Sparrows [Zonotrichia leucophrys]; Baptista 1975), to many (e.g. 10 to 60 in Sedge Warblers [Acrocephalus schoenobaenus]; Catchpole 1980), to hundreds (e.g. Common Nightingales [Luscinia megarhynchos]; Hultsch and Todt 1989), to even thousands (e.g. Brown Thrashers [Toxostoma rufum]; Boughey and Thompson 1981). At the population level, species differ in the similarity of songs of neighbors. At one extreme, individuals can share most or all of their song types with neighbors, resulting in considerable spatial structure and very sharp boundaries between different song dialects (i.e. miocrogeographic variation). At the other extreme, songs of neighbors can be dissimilar, with little geographic structure in the distribution of song types. Species also differ in the degree to which they copy songs of other birds they hear during song development. Some species tend to faithfully imitate the songs they hear, whereas others tend to improvise and develop individually distinct songs (Kroodsma 1996).

Since the pioneering work of Thorpe (1958) on song learning in Chaffinches (Fringilla coelebs), many laboratory studies have been conducted on developmental aspects of song learning. These important lab studies, by necessity, have focused on proximate "how" questions and have revealed much about the endocrine, 
neurological, anatomical, and developmental mechanisms of song learning (see Nottebohm 1993, Marler 1984, Catchpole and Slater 1995, Beecher 1996, Hauser 1996). Lab studies, however, cannot begin to replicate the complex ecological and social factors that undoubtedly play a crucial role in the evolution of vocal behavior of song birds. Kroodsma (1996:4) has framed this in saying: "Exactly what can laboratory studies ... tell us about how birds behave in nature? ... I am increasingly convinced that laboratory studies can at most show only what a bird is capable of doing in an environment never encountered before in the species' evolutionary history."

How, for example, do migratory habits, dispersal characteristics, intensity of sexual selection, mating systems, habitat type, predation and parasitism, phylogeny, and other ecological and social variables influence the evolution of vocal behavior? Although many studies have investigated some of these factors (e.g. Morton 1975, Catchpole 1982, Searcy and Andersson 1986), many field studies are descriptive and remain unconnected to any larger set of hypotheses. We currently lack a coherent conceptual model that explains the diversity of singing behavior and song learning programs in an evolutionary framework. A widespread need now exists for comparative studies, involving both laboratory analyses and fieldwork, that investigate the ultimate mechanisms that influence the evolution of vocal behavior (Catchpole and Slater 1995, Hauser 1996, Kroodsma 1996).

In this issue of The Auk, Kroodsma et al. examine differences in song development between Marsh Wrens (Cistothorus palustris) and North American Sedge Wrens (Cistothorus platensis). Their work is an exciting example of the type of comparative study that can shed new light on the evolution of vocal behavior and song learning styles. Don Kroodsma and his colleagues have combined lab and field studies of two Cistothorus wrens whose vocal behaviors appear to differ in fundamental ways. Males of both species have large repertoires, with individuals singing 50 to 200 different song types. However, the species differ markedly in the degree of song sharing in local populations. Marsh Wrens tend to share many song types with neighbors, engage in bouts of matched countersinging during territorial interactions, and have song dialects that vary geographical- ly. In contrast, male Sedge Wrens share few song types with neighbors and show little geographic variation in dialect structure. Earlier lab studies showed that young Marsh Wrens learn by imitation, faithfully copying tutor songs played to them on speakers (Kroodsma and Pickert 1984). Previous studies with Sedge Wrens suggested that young males improvise rather than imitate songs (Kroodsma and Verner 1978). These studies were based on only three birds, however, and an alternative hypothesis remained that Sedge Wrens learn by imitation, but disperse long distances from where they were born, which would also result in no recognizable geographic song dialects.

What ecological and social factors are responsible for these differences in vocal behavior and possible differences in song learning programs (i.e. imitation vs. improvisation)? Both Marsh Wrens and Sedge Wrens breed in high densities and can have highly polygynous mating systems. However, differences in the stability of their breeding habitats may influence other important characteristics of their life histories. Marsh Wrens breed in relatively stable marshes, and they are either year-round residents, or if migratory, they show a high degree of site fidelity. Sedge Wrens breed in more ephemeral wet meadows, and it has been suggested that they are highly nomadic, opportunistic colonizers of these unpredictable habitats. Different song-learning programs may be favored in breeding habitats that differ in temporal stability. Highly philopatric Marsh Wrens that learn by imitation when they are young would thus develop a catalog of songs shared with neighbors. This imitative songlearning developmental program, coupled with relatively low dispersal, would reduce variation between individuals while maximizing geographic differentiation. North American Sedge Wrens may develop songs by improvisation from a basic species-specific template. Such a song-learning program would maximize individual variation while minimizing geographic differentiation. This improvisatory song-learning program would result in a wider signal audience, allowing a male to communicate with other Sedge Wrens no matter where it ended up.

Although these general hypotheses had been formulated in the 1970s, the sample sizes of the preliminary work were small, and many of the 
underlying assumptions remained untested. Kroodsma and his co-workers (1999) have returned to this fascinating comparison. To unambiguously demonstrate that North American Sedge Wrens do learn by improvisation they captured nestlings from North Dakota and brought them into captivity. The young birds were exposed to a training tape for a year, and the young males could see and hear each other. Each male developed unique songs that were unlike those of the training tape or the other males (although they contained elements that were similar to the training tapes). Concurrent field studies confirmed that North American Sedge Wrens are highly mobile and opportunistically disperse and settle in suitable habitat when it becomes available between May and October. These lab and field studies confirm that song-learning programs of Marsh Wrens and Sedge Wrens are different. The results are further bolstered with conspecific comparisons of more sedentary populations of South American Sedge Wrens. In Brazil, for example, Sedge Wrens breed in more stable habitats and are ecologically and socially more similar to North American Marsh Wrens than to North American Sedge Wrens; Braziliar $\rightarrow$ males learn songs by imitation, and birds within the same marsh share many song types and engage in matched countersinging in a manner similar to that of North American Marsh. Wrens.

Kroodsma et al.'s study is an exciting example of how comparisons between judiciously chosen species can help frame hypotheses about the selective pressures that act on bird songs. With the example set by these researchers, we can look forward to more studies that illuminate the how as well as the why of song learning and vocal behavior in oscines.

\section{Literature Cited}

ANONYMOUS. 1717. The bird fancyer's delight. Richard Mearnes, London.

BAPTISTA, L. F. 1975. Song dialects and demes in sedentary populations of the White-crowned Sparrow (Zonotrichia leucophrys nuttalli). University of California Publications in Zoology 105:1-52.

BEECHER, M. D. 1996. Birdsong learning in the lab $\rightarrow$ oratory and field. Pages 61-78 in Ecology and evolution of acoustic communication in birds (D.
E. Kroodsma and E. H. Miller, Eds.). Cornell University Press, Ithaca, New York.

Boughey, M. J., AND N. S. ThOMPSON. 1981. Song variety in the Brown Thrasher (Toxostoma rufum). Zeitschrift für Tierpsychologie 56:47-58.

Catchrole, C. K. 1980. Sexual selection and the evolution of complex songs among European warblers of the genus Acrocephalus. Behaviour 74: 149-166.

CATChPOLE, C. K. 1982. The evolution of bird sounds in relation to mating and spacing behavior. Pages 297-319 in Acoustic communication in birds, vol. 1 (D. E. Kroodsma and E. H. Miller, Eds.). Academic Press, New York.

Catchpole, C. K., and P. J. B. Slater. 1995. Bird song: Biological themes and variations. Cambridge University Press, Cambridge, United Kingdom.

Hauser, M. D. 1996. The evolution of communication. MIT Press, Cambridge, Massachusetts.

Hultsch, H., AND D. TODT. 1989. Song acquisition and acquisition constraints in the Nightingale, Luscinia megarhynchos. Naturwissenschaften 76 : 83-85.

KroOdSMA, D. E. 1996. Ecology of passerine song development. Pages 3-19 in Ecology and evolution of acoustic communication in birds (D. E. Kroodsma and E. H. Miller, Eds.). Cornell University Press, Ithaca, New York.

Kroodsma, D. E., W.-C. LiU, E. Goodwin, And P. A. BEDELL. 1999. The ecology of song improvisation as illustrated by North American Sedge Wrens. Auk 116:373-386.

Kroodsma, D. E., AND R. Pickert. 1984. Sensitive phases for song learning: Effects of social interaction and individual variation. Animal Behaviour 32:389-394.

Kroodsma, D. E., AND J. Verner. 1978. Complex singing behaviors among Cistothorus wrens. Auk 95:703-716.

MARLER, P. 1984. Song learning: Innate species differences in the learning process. Pages 289-309 in The biology of learning (P. Marler and H. S. Terrance, Eds.). Springer-Verlag, New York.

MORTON, E. S. 1975. Ecological sources of selection on avian sounds. American Naturalist 109:1734.

Notтeвohm, F. 1993. The search for neural mechanisms that define the sensitive period for song learning in birds. Netherlands Journal of Zoology 43:193-234.

SEARCY, W. A., AND M. ANDERSSON. 1986. Sexual selection and the evolution of song. Annual Review of Ecology and Systematics 17:507-533.

THORPE, W. H. 1958. The learning of song patterns in birds, with especial reference to the song of the Chaffinch, Fringilla coelebs. Ibis 100:535-570. 